\title{
Erratum to: Economic risk assessment of Cotopaxi volcano, Ecuador, in case of a future lahar emplacement
}

\author{
Fabian Rodriguez ${ }^{1,2}$ - Theofilos Toulkeridis ${ }^{1,3}$. \\ Washington Sandoval ${ }^{1} \cdot$ Oswaldo Padilla $^{1}$. \\ Fernando Mato ${ }^{1,4}$
}

Published online: 9 November 2016

(C) Springer Science+Business Media Dordrecht 2016

\section{Erratum to: Nat Hazards DOI 10.1007/s11069-016-2589-1}

In paragraphs $12-16$ of Sect. 3 Economic risk assessment of the surrounding of the Cotopaxi volcano the decimal point in many figures was omitted. The affected paragraphs are given again below and the corrected figures are displayed in bold type.

A further critical and basic resource, which will be severely affected by Cotopaxi's lahars, is water and water supply. Future lahars will affect approximately 925,000 people from cities of Quito, Latacunga, as well as Lasso and Salcedo towns and the Los Chillos valley (Table 5). These cities and towns have their main source of water supplied from the Cotopaxi volcano and its surrounding. Water revenue losses were estimated based on individual consumption, which has been projected by FAO for Ecuador (FAO-Aquastat 2005). The average water consumption in Ecuador is $100 \mathrm{~L} /$ person/day. The price of water varies from town to town. In the city of Quito, price for consumers is $\mathbf{1 . 0 0} \mathrm{US} \$ / \mathrm{m}^{3}$ up to $10 \mathrm{~m}^{3}$ and additional $\mathbf{2 . 0 0} \mathrm{US} \$ / \mathrm{m}^{3}$ if consumers consumption is above that volume. In Mejia Canton, the actual price is about $1.11 \mathrm{US} \$ / \mathrm{m}^{3} / \mathrm{month}$, and in Ambato city, the price is of about 3.47 US\$/month $/ 10 \mathrm{~m}^{3}$. Based on this price variability, we have used a value of 1.00 US $\$ /$ L/day as a reasonable average price, and then, we added an additional $0.20 \mathrm{US} \$$

The online version of the original article can be found under doi:10.1007/s11069-016-2589-1.

Theofilos Toulkeridis

ttoulkeridis@espe.edu.ec; theousfq@yahoo.com

1 Centro Geoespacial, Universidad de las Fuerzas Armadas ESPE, Sangolquí, Ecuador

2 Facultad de Economía, Pontificia Universidad Católica del Ecuador, Quito, Ecuador

3 Centro Panamericano de Estudios e Investigaciones Geográficas (CEPEIGE), Quito, Ecuador

4 Universidad de Cuenca, Cuenca, Ecuador 
for transportation cost. These values are based on standard value established by each city and town. The product of water price, transportation costs and water consumption results to water revenue losses, as detailed in Table 5. Our assumption leads to total days off of water, which will be of about 15 days, as all contingency plans for emergencies in this region guarantee water provision in less than a week. Therefore, it is reasonable to assume that it will take at most 15 days for full water supply recovery.

Cotopaxi volcano eruption and subsequent generation of lahars will also affect food supply and provision, but similar to the case of water supply, we assume that this will take only 15 days to re-establish the known food chain. In order to estimate food revenue losses, we have considered an average of individual consumption on monetary terms of $\mathbf{5 . 0 0}$ US\$/day. Therefore, we determined the population affected, as well as the number of meals per day and storage area in cubic meters. We have added to this value a transportation cost, being an average of $0.20 \mathrm{US} \$ / \mathrm{km} / \mathrm{m}^{3}$ (Table 6).

As food supply will depend directly on transportation, we have added to water and food supply a cost of $0.20 \mathrm{US} \$ / \mathrm{km} / \mathrm{m}^{3}$, still it will not represent the total loss of revenues of transportation. Our estimation on transportation revenues loss takes into account an estimated number of transportation units reaching to Quito from northern and southern provinces every day. On the estimation of an average volume transportation size of about $5 \mathrm{~m}^{3}$, we have added additionally a transport distance of about $150 \mathrm{~km}$. Revenue loss in transportation is therefore of about $\mathbf{1 9 . 0 1}$ million US\$ as indicated in Table 7.

The tourism sector has also been included in the potential economic losses, being estimated from weekly profits from local spa and public pools. Recreational sites every week at the Chillos valley are joined by 4500 visitors, who spent an average of some $\mathbf{7 . 0 0}$ US\$/day (El Comercio 2015). Based on this, we have estimated that economic damages on these public facilities will be critical since they are located at the San Pedro's river bank, the natural northern exit flow for Cotopaxi's lahars after the culmination of the lahars of the rivers Santa Clara and Pita (Fig. 1). We have also estimated that it will require approximately 1 year to full recovery of this tourist spot. Accordingly, revenue losses from local tourism will reach approximately some 164 million US\$.

In addition to local revenues lost, Cotopaxi volcano is a national protected area, which covers approximately 32,000 ha (Jácome 2009). The Cotopaxi National Park receives an average of 149,000 visitors each year, of which $72 \%$ are nationals and $28 \%$ are foreigners. It has been problematical to estimate economic losses or potential losses as local markets do not generally keep records of their transactions and publish even less. Nevertheless, we have estimated potential losses of tourism of the Cotopaxi National Park based on a study by Rodríguez et al. (2008). The Cotopaxi National Park has been closed during 119 days, and our estimate of economic losses is based on per day benefit losses of tour operators and local markets. The mentioned study is about seven protected areas in Ecuador including Cotopaxi National Park in which it has been differentiated between national and foreign tourists (Rodríguez et al. 2008). They establish that tour operator costs varied from 20 US\$/day to up to $175 \mathrm{US} \$$ /day for a tour package of 3-4 days. In addition, it has been estimated that each tourist spends between 5 US\$ and 50 US\$/day. Based on such assumptions, we assumed that the tour operator cost per day for a tourist for Cotopaxi National Park has been of about 60.00 US\$ with some additional expenses for each tourist being of another 30.00 US\$. As a result, we estimated that economic benefit losses during those referred 119 days reached about 4,386,716.24 US\$. 